УДК 343.131

DOI https:// doi.org/10.32837/yuv.v0i1.1533

\author{
О. Бойко, \\ суддя \\ Голосіївського районного суду міста Києва
}

\title{
СПРАВЕДЛИВІСТЬ ЯК КАТЕГОРІЯ КРИМІНАЛЬНОГО ПРОЦЕСУАЛЬНОГО ПРАВА
}

Справедливість $є$ фундаментом правової держави. Ще з часів римського права відомі такі юридичні афоризми: «lex iniusta non est lex» (несправедливий закон не $є$ законом), «justitia in suo cuique tribuendo cernitur» (справедливість полягає у відплаті кожному по його заслугах). Саме справедливість $€$ орієнтиром у правотворчій, правозастосовній, правоохоронній та інших видах людської діяльності, є загальнолюдською цінністю, основою прогресивного розвитку держави та іi інститутів [1, с. 206].

Постійне й системне вдосконалення кримінального процесуального законодавства вимагає однозначного розумінні сутності та змісту справедливості як категорії кримінального процесу, адже чіткість і зрозумілість термінів, які вживаються в кримінальних процесуальних нормах, є запорукою досягнення справедливості кримінального провадження.

Справедливість у кримінальному процесі досліджували або через призму засад кримінального провадження, або як властивість судового рішення такі вчені: Н.Р. Бобечко, О.А. Кучинська, Г.М. Мамка, В.В. Михайленко, О.Б. Прокопенко, М.А. Погорецький, Н.П. Сиза, О.С. Ткачук, В.М. Тертишник, О.Г. Шило. Утім сталого й загальновизнаного підходу до визначення сутності справедливості як категорії кримінального процесуального права серед науковців не існує.

Метою статті $є$ аналіз наукових підходів до визначення сутності справедливості та їі нормативного закріплення як категорії кримінального процесуального права, з'ясування змісту цього правового феномена.

Насамперед варто зауважити, що термін «справедливість» $€$ вимогою до досить широко кола суспільних відносин та охоплює його різноманітні аспекти: характеристику людини, правової норми, певних процесів (юридичних, економічних, соціальних). Зокрема, О.Б. Прокопенко відмічає, що, відповідно до двох вимірів соціального буття (персонального та інституційного), можна виділити два поняття справедливості: а) справедливість як характерна риса особистості; б) справедливість, що стосується соціальних інститутів (родина, господарство, школа), а також політична справедливість, що стосується права, держави й політики [2, с. 9].

$\mathrm{y}$ філософських дослідженнях, як правило, виділяють формальну, змістову та процедурну справедливість. Так, О.А. Кучинська зазначає, що основна ідея формальної справедливості втілюється в принципі формальної рівності, що конкретизується у вимогах рівності перед законом і судом, рівності прав, свобод та обов'язків людини. Змістова справедливість утілюється в принципі пропорційності, а тому вимагає пропорційності юридичної відповідальності вчиненому правопорушенню. Процедурна справедливість виражається в додержанні процедурних правил, що спрямовані на забезпечення справедливості результату, тієї чи іншої дії, незалежно від інших обставин [3]. 


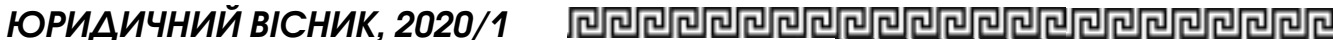

Разом із цим, як зауважує В.M. Тертишник, у філософії права виділяють такі аспекти поняття «справедливість»: справедливість як рівність можливостей у реалізації своїх здібностей і захисту своїх прав і законних інтересів; справедливість розподільчу - справедливий розподіл благ, виходячи з потреб кожної людини, юридичної рівності людини та 3 урахуванням іï праці й заслуг перед суспільством і державою; справедливість відплатну - справедливість відповідальності за вчинені злочин чи правопорушення [4, с. 159].

Така багатоаспектність і масштабність сутності терміна «справедливість» як загальнофілософської чи загальноправової категорії зумовила аналогічні підходи до тлумачення цієї категорії в галузевих правових науках, зокрема й у теорії кримінального процесуального права. Так, Н.Р. Бобечко відмічає, що в доктрині кримінального процесу поняття «справедливість» уживається в чотирьох контекстних значеннях: як цінність кримінального провадження; як мета кримінального провадження; як засада кримінального провадження; як невід'ємний елемент змісту судового рішення, критерій його правосудності й оцінювання ефективності й легітимності діяльності судової влади [5].

Ураховуючи вищенаведені твердження науковців і здійснивши аналіз норм кримінального процесуального законодавства, можемо стверджувати, що в кримінальному процесі «справедливість» уживається в таких контекстних значеннях: як мета, завдання кримінального провадження, як засада кримінального провадження, як суб'єктивне право на справедливий судовий розгляд, як вимога до судового рішення, як відповідність покарання, що призначається судом, як вимога до характеристики присяжного.

Як мета, завдання кримінального провадження. У процесуальній літературі справедливість визнається як завданням, так і метою кримінального провадження.
Так, Н.P. Бобечко наголошує, що справедливість є правовим ідеалом кримінального провадження та визначає мету правового регулювання кримінальних процесуальних відносин, орієнтує діяльність суб'єктів кримінального провадження на досягнення певних зразків поведінки, слугує критерієм для оцінювання процесуальних рішень, дій чи бездіяльності суб'єктів кримінальних процесуальних відносин [5].

На думку Г.М. Мамки, справедливість $€$ завданням правосуддя в широкому значенні (не лише як діяльності суду), як реакція на несправедливість - учинення кримінального правопорушення [1, с. 208]. Варто зауважити, що в інших процесуальних галузях права, на відміну від Кримінального процесуального кодексу (далі КПК) України, справедливість судового розгляду закріплена в процесуальних кодексах саме як завдання судочинства, зокрема в ст. 2 Цивільного процесуального кодексу України.

Співвідношення між метою та завданням можемо знайти в працях В.M. Тертишника, де він відмічає, що мета - це уявна модель бажаного результату. Тому мета кримінального процесу - це захист громадян, юридичних осіб і держави від злочинних посягань, забезпечення справедливості кримінального провадження, а завдання - це те, що має бути зроблено для досягнення мети. Тому серед завдань кримінального процесу вчений називає й забезпечення справедливого правосуддя [4, с. 8].

Отже, справедливість кримінального провадження $€$ як його метою, так і завданням, адже справедливість i $є$ тим орієнтиром, задля досягнення якого розпочинається кримінальне провадження: щоб кожний, хто вчинив кримінальне правопорушення, був притягнутий до відповідальності в міру своєї вини, жоден невинуватий не був обвинувачений або засуджений. Водночас завданням кримінального провадження є дотримання справедливої процедури: щоб жодна особа не була 


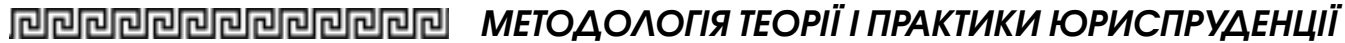

піддана необгрунтованому процесуальному примусу та щоб до кожного учасника кримінального провадження була застосована належна правова процедура.

Як засада кримінального провадження. У теорії кримінального процесу серед науковців можна зустріти різні думки щодо того, чи є справедливість засадою кримінального провадження. Такі дискусії зумовлені тим, що ні ст. 129 Конституції України, ні Закон України «Про судоустрій і статус суддів», ні ст. 7 КПК України не містять прямого легального закріплення принципу (засади) справедливості [1, с. 207].

Так, дійсно, у ст. 7 КПК України в загальному переліку засад справедливість не виокремлена як засада кримінального провадження. Але разом із цим у контексті засади «доступ до правосуддя та обов'язковість судових рішень», яка визначена в п. 14 ст. 7 і розкривається в положеннях ст. 21 КПК України, закріплено, що «кожному гарантується право на справедливий розгляд та вирішення справи» [6]. Тобто в цій нормі в контексті засади доступу до правосуддя й обов'язковості судових рішень ідеться про гарантування права на справедливий судовий розгляд.

Проте така законодавча регламентація не дає змоги зробити однозначний висновок щодо нормативного закріплення справедливості як засади кримінального провадження, адже прямого текстуального закріплення ми не знайдемо в нормах кримінального процесуального закону. Разом із цим законодавець оперує терміном «засада справедливого судочинства» в ч. 2 ст. 550 КПК України, де визначаються вимоги щодо допустимості доказів, отриманих у результаті виконання дій, передбачених у запиті про міжнародне співробітництво [6].

Неналежне унормування справедливості як засади кримінального процесуального права зумовлює такі запитання: чи є вимога справедливості окремою засадою кримінального провадження; якщо так, то де іï місце в сис- темі засад кримінального провадження; чи потребує вона окремого законодавчого закріплення?

Так, поширеною серед учених-процесуалістів є думка, що, незважаючи на відсутність нормативного закріплення, справедливість є самостійною засадою кримінального провадження. Зокрема, B.M. Тертишник стверджує, що, окрім указаних у ст. 7 КПК України, до принципів кримінального процесу варто зарахувати в тому числі й справедливість [4, с. 107-108]. Як зауважує О.А. Кучинська, принцип справедливості в кримінальному процесі України виконує координувальну роль у системі українського законодавства. Він проходить «червоною» смугою серед усіх принципів кримінального судочинства, визначає ї дію в конкретних умовах простору та часу [3].

Досить часто в наукових працях можемо зустріти ототожнення засад верховенства права та справедливості. Так, О.С. Ткачук уважає, що право на справедливий судовий розгляд є елементом принципу верховенства права [7, с. 189].

Справедливість цілком обгрунтовано вважається загальноправовою засадою кримінального провадження. Загальноправові засади в кримінальному процесі одержують нове теоретичне осмислення, змістовне збагачення та юридичний розвиток, набувають суто процесуального змісту [4, с. 109] і мають свою специфіку залежно від особливостей кримінальних процесуальних відносин [8, с. 123]. Зокрема, специфікою справедливості в кримінальному процесі $€$ те, що вона має охоплювати єдність і процедурної (процесуальної), і змістової (матеріальної) справедливості, а тому особливості дії загальноправових принципів під час кримінального провадження повинні мати нормативне закріплення.

Засада справедливості в кримінальному провадженні тісно переплітається 3 іншими його засадами. Так, В.В. Михайленко відмічає, що забезпечення справедливості кримінального 
провадження базується на дотриманні верховенства права, тоді як належна правова процедура, у процесі якої ця справедливість досягається, опирається на верховенство закону [9, с. 61-62]. Г.М. Мамка стверджує, що справедливість за своєю загальноправовою сутністю збігається 3 принципом формальної рівності [8, с. 122] та близька до законності й навіть тісно пов'язана 3 нею, однак не тотожна їй, проявляючи власний самостійний зміст і значення [1, с. 209-210].

Отже, загальноправовий принцип справедливості поширюється на кримінальне процесуальне право, набуваючи своєї специфіки, зумовленої особливостями кримінальних процесуальних правовідносин. Справедливість є окремою та самодостатньою засадою кримінального провадження, тому, ураховуючи відсутність належної законодавчої регламентації вимоги справедливості кримінального провадження та фундаментальне значення цієї категорії для кримінального судочинства, підтримуємо вчених, які звертають увагу на необхідність іï унормування, присвятивши їй окрему норму в главі 2 КПК України.

Як суб’єктивне право на справедливий судовий розгляд. У нормах КПК України право на справедливий судовий розгляд текстуально закріплено в контексті врегулювання інших питань кримінального провадження (ч. 1 ст. 21, ч. 5 ст. 474 КПК України). Утім право на справедливий судовий розгляд закріплено в ст. 6 Європейської конвенції про захист прав і основоположних свобод людини (далі - ЄКПЛ) та обгрунтовано визнається європейським стандартом забезпечення прав людини під час здійснення судочинства загалом і кримінальних проваджень зокрема.

Стандарти судочинства, визначені в ЄКПЛ, відіграють важливу роль у вітчизняному правозастосуванні. Вони виконують функції виявлення й усунення прогалин i колізій кримінального процесуального законодавства в частині забезпечення прав людини; орієнтування під час формування кримінального процесуального законодавства; установлення меж примусового втручання державних органів у права людини в ході кримінального провадження; відновлення порушених прав людини у сфері кримінального судочинства $[10$, с. $8 ; 9$, с. 46-47].

Варто зауважити, що право на справедливий судовий розгляд $€$ комплексним і багатоаспектним. Його зміст, як правило, розкривається за допомогою аналізу положень ст. 6 ЄКПЛ «Право на справедливий суд», яка складається 3 трьох частин, де в ч. 1 ст. 6 ЄКПЛ визначено загальні правила права на справедливий суд, у ч. 2 ст. 6 ЄКПЛ презумпцію невинуватості як спеціальну гарантію кримінального судочинства, а в ч. 3 ст. 6 ЄКПЛ - специфічні гарантії справедливості кримінального провадження [9, с. 176-177].

Разом із цим Н.P. Бобечко зауважує, що право на справедливий суд, закріплене в ст. 6 ЄКПЛ, не обмежується перерахованими в ній елементами. Ці елементи утворюють лише необхідний minimum minimorum, свого роду condition sine qua non, що не звільняє від обов'язку дотримання інших засад і гарантій, пов'язаних із поняттям «правосуддя». Європейський суд $з$ прав людини поступово наповнює зміст права на справедливий суд новими положеннями, забезпечуючи гармонізацію засад судочинства [5].

Як вимога до судового рішення. У нормах КПК України, які регламентують судові стадії кримінального провадження, термін «справедливість» уживається в контексті «справедливого судового рішення» (ч. 3 ст. 337, ч. 1 ст. 410 КПК України). Зокрема, у ст. 410 КПК України передбачено, що неповним визнається судовий розгляд, під час якого залишилися недослідженими обставини, з'ясування яких може мати істотне значення для ухвалення законного, обгрунтованого та справедливого судового рішення.

У наведеній нормі справедливість уживається в контексті триє- 


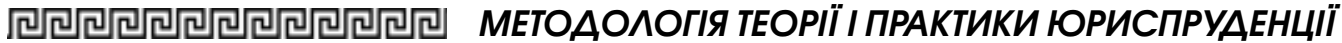

диної вимога до судового рішення законне, обгрунтоване та справедливе судове рішення, але це при тому, що в ч. 1 ст. 370 КПК України визначено, що судове рішення має бути законним, обгрунтованим і вмотивованим. I якщо в ст. 370 КПК України законодавець визначає критерії законності, обгрунтованості й умотивованості судового рішення, то щодо того, яке рішення варто вважати справедливим і від чого варто відштовхуватися, визначаючи справедливість чи несправедливість судового рішення, законодавець не вказує.

Очевидно, що така позиція зумовлена масштабністю та багатоаспектністю цього терміна, а також тим, що справедливість $є$ морально-правовою категорією, яку неможливо чітко визначити в нормативному акті. Уважаємо, що справедливість прийнятого рішення, як і справедливість проведення процесуальних дій, $€$ складниками засади справедливості кримінального провадження, адже справедливими мають бути як процесуальні рішення, так і процедури, на підставі яких прийняті ці рішення.

Як відповідність покарання, що призначається судом. Так, у ч. 1 ст. 414 КПК України вказано, що невідповідним ступеню тяжкості кримінального правопорушення та особі обвинуваченого визнається таке покарання, яке хоча й не виходить за межі, установлені відповідною статтею (частиною статті) закону України про кримінальну відповідальність, але за своїм видом чи розміром $€$ явно несправедливим через м'якість або через суворість [6]. Тобто в цьому разі законодавець термін «справедливість/несправедливість» використовує для характеристики визначеного судом покарання, яке хоча й прийняте в межах, установлених законом, але водночас не відповідає вимозі справедливості (відповідності, об’єктивності).

Однак справедливість у кримінальному провадженні не може бути обмежена призначенням покарання або зага- лом питаннями кримінально-правового характеру. Справедливими мають бути й процедури, що застосовуються під час вирішення цих питань [1, с. 209].

Окрім цього, предметом кримінального процесуального регулювання $€$ справедливість кримінальної процесуальної форми, а не покарання, а запорукою призначення справедливого покарання і є дотримання визначеного законом порядку здійснення процесуальних дій і прийняття процесуальних рішень.

Як вимога до характеристики присяжного. Так, у ч. 2 ст. 388 КПК України наведено текст присяги присяжних: «Я (прізвище, ім'я по батькові), присягаю виконувати свої обов'язки чесно і неупереджено, брати до уваги лише досліджені в суді докази, при вирішенні питань керуватися законом, своїм внутрішнім переконанням і совістю, як личить вільному громадянину і справедливій людині» [6]. Аналогічні положення $€$ й у тексті присяги професійних суддів (ч. 1 ст. 57 Закону України «Про судоустрій та статус суддів»). Утім у цьому разі термін «справедливість» стосується не характеристики кримінального провадження, а використовується в контексті морально-етичної характеристики особи судді чи присяжного - чесність, неупередженість, об'єктивність.

У кримінальному процесуальному законодавстві справедливість уживається в таких контекстних значеннях: як морально-етична вимога до характеристики особи, як вимога матеріального права (справедливість покарання, що призначається судом), як вимога до процесуальної форми (дотримання справедливої процедури проведення процесуальних дій i прийняття процесуальних рішень). Справедливість як вимога до процесуальної форми також багатоаспектна: $\varepsilon$ метою (завданням) кримінального провадження, засадою кримінального провадження та процесуальним правом особи (право на справедливий судовий розгляд). 


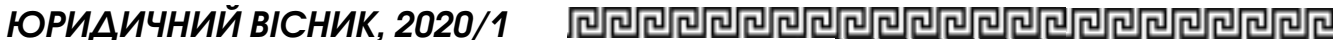

Стаття присвячена дослідженню наукових підходів до визначення сутності справедливості та ї нормативного закріплення як категорії кримінального процесуального права.

3'ясовано, щзо у філософських дослідженнях виділяють формальну, змістову й проиедурну справедливість. У філософії права розрізняють справедливість як рівність можливостей, справедливість розподільчу та справедливість відплатну. У кримінальному проиесі справедливість уживається в таких контекстних значення: як мета (завдання) кримінального провадження, як засада кримінального провадження, як суб'єктивне право на справедливий судовий розгляд, як вимога до судового рішення, як відповідність покарання, як вимога до характеристики присяЖного.

Обгрунтовано, щзо справедливість кримінального провадження $є$ як його метою, так $і$ завданням. Справедливість є тим орієнтиром, задля досягнення якого розпочинається кримінальне провадження, а завданням кримінального провадження $є$ дотримання справедливої процедури.

Визначено, що загальноправовий принции справедливості поширюється на кримінальне прочесуальне право, набуваючи своєї специціки, зумовленої особливостями кримінальних прочесуальних правовідносин. Справедливість є окремою та самодостатньою засадою кримінального провадження.

Установлено, щз предметом кримінального процесуального регулювання є справедливість кримінальної проиесуальної форми, а не покарання.

Обгрунтовано, щзо в кримінальному процесуальному законодавстві справедливість уживається в таких значеннях: як морально-етична вимога до характеристики особи, як вимога матеріального права (справедливість покарання, що призначається судом), як вимога до прочесуальної форми (дотримання справедливої процедури проведення проиесуальних дій $і$ прийняття процесуальних рішень). Справедливість як вимога до процесуальної форми також є багатоаспектною: є метою (завданням) кримінального провадження, засадою кримінального провадження та процесуальним правом особи (право на справедливий судовий розгляд).

Ключові слова: справедливість, засада кримінального провадження, право на справедливий судовий розгляд, справедливе судове рішення, справедливе покарання.

Boyko O. Fairness as a category of criminal procedural law

The article is devoted to the research of scientific approaches to defining the essence of fairness and its normative fixing as a category of criminal procedural law.

It is found that in philosophical studies distinguish formal, substantive and procedural justice. In philosophy of law distinguishes: fairness as equality of opportunity, fairness distributive and revengeful fairness. In criminal proceedings fairness is used in such contextual meanings: as the purpose (task) of criminal proceedings, as the principle of criminal proceedings, as a subjective right to a fair trial, as a requirement to a judicial decision, as an accordance of punishment, as a requirement to the characteristic of a jury.

It is substantiated that the fairness of criminal proceedings is both its purpose and its task. Fairness is that reference point, to achieve which criminal proceeding is initiated, and the task of criminal proceedings is to follow a fair procedure.

It is determined that the general law principle of fairness extends to criminal procedural law, taking on its own specificity, due to the peculiarities of criminal procedural relations. Fairness is a separate and self-sufficient principle of criminal proceedings. 


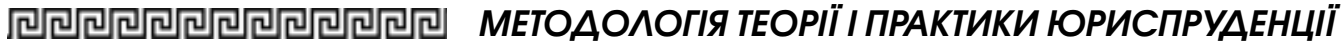

It is established that the subject of criminal procedural regulation is the fairness of the criminal procedural form, not punishment.

It is substantiated that in the criminal procedural legislation fairness is applied in the following meanings: as a moral and ethical requirement for the characteristics of a person, as a requirement of substantive law (justice of punishment appointed by a court), as a requirement to the procedural form (compliance with the fair procedure of processual actions and making procedural decisions). Fairness as a requirement to a procedural form is also multidimensional: it is the purpose (task) of criminal proceedings, the principle of criminal proceedings, and the procedural right of a person (right to a fair trial).

Key words: fairness, principle of criminal proceedings, right to a fair trial, fair court decision, fair punishment.

\section{Література}

1. Мамка Г.м. Засади кримінального провадження: наукові та правові основи : дис. ... докт. юрид. наук : 12.00.09. Київ, 2019. 466 c

2. Прокопенко О.Б. Право на справедливий суд : автореф. дис. ... канд. юрид. наук : 12.00.10. Харків, 2011. 20 c.
3. Кучинська О.А. Зміст принципу справедливості у кримінальному судочинстві України. Часопис Національного університету «Острозька академія». Серія «Право». 2011. № 1 (3). URL: https://lj.oa.edu.ua/ articles / 2011 /n1/ 11koaksu.pdf.

4. Тертишник B.М. Кримінальний проиес Украӥни. Загальна частина: підручник. Kuїв : Aлерта, 2014. 440 c.

5. Бобечко H.P. Справедливість як иінність кримінального провадження. Часопис Національного університету «Острозька академія». Серія «Право». 2017. № 1 (15). URL: https: / / li.oa.edu.ua / articles / 2017/ n1/17bnrtkp.pdf.

6. Кримінальний процесуальний кодекс України : Закон України від 13.04.2012 № 4651-VI. URL: https: / / zakon.rada.gov.ua/ laws / show/4651-1775.

7. Ткачук О. Витоки сучасного розуміння права на справедливий суд. Visegrad Journal on Human Rights. 2016. № 1/2. C. 188-193.

8. Мамка Г.М. Справедливість як категорія та засада кримінального провадження. Науковий вісник Ужгородського національного університету. Серія «Право». 2018. № 48. С. 120-124.

9. Михайленко В.В. Реалізація засади верховенства права у кримінальному провадженні : монографія. Київ : Паливода А.В., 2019. 256 c.

10. Сімонович Д.В. Європейські стандарти забезпечення прав людини у досудових стадіях кримінального процесу України : автореф. дис. ... канд. юрид. наук : 12.00.09. Харків, 2011. 20 c. 